\title{
CYR61 Gene
}

National Cancer Institute

\section{Source}

National Cancer Institute. CYR61 Gene. NCI Thesaurus. Code C113315.

This gene plays a role in apoptosis, angiogenesis, heart development and many other processes. 